\title{
First report of Fusarium solani species complex as a causal agent of Erythrina variegata decline and death after gall formation by Quadrastichus erythrinae on Okinawa Island, Japan
}

\author{
Keiko Kuroda ${ }^{1}$ Izumi Chuma $^{1}$ - Takeo Kihara ${ }^{1}$ ' Tsubasa Murakami ${ }^{1}$ • \\ Kuya Takashina $^{1}$ - Daiki Hiraoka ${ }^{1} \cdot$ Norikazu Kameyama $^{2}$
}

Received: 27 December 2016 / Accepted: 18 August 2017 / Published online: 21 September 2017

(c) The Author(s) 2017. This article is an open access publication

\begin{abstract}
The defoliation and mortality of Erythrina spp. are increasing on the southern islands of Japan as well as in Taiwan. Although infestation by the gall wasp Quadrastichus erythrinae has been accepted as the cause of Erythrina decline, its role in the death of hosts has never been investigated. We thus studied the cause of the decline, focusing on physiological changes and any contributions by microorganisms. From declining and defoliated trees, Fusarium sp. within $F$. solani species complex (FSSC) clade 3 was primarily detected, especially from discolored xylem and necrotic phloem that had an odor. This fungus belongs to the Ambrosia Fusarium clade, a group of symbionts of ambrosia beetles that includes the causal agent of Fusarium dieback on avocado. No specific fungi were detected from twigs and leaves with $Q$. erythrinae galls. According to histological observations, the internal symptoms of declining E. variegata are similar to those of sudden death syndrome in soybeans, which is caused by $F$. virguliforme, a member of FSSC clade 2. One of the isolates of the Fusarium sp. isolated from E. variegata induced wilt and necrosis of cortex and phloem in the seedlings after artificial inoculation, and the inoculated strain was reisolated. The present results demonstrated that the isolate was pathogenic to $E$. variegata and may be a causal agent of Erythrina decline.
\end{abstract}

Keiko Kuroda

kurodak@garnet.kobe-u.ac.jp

$\triangle$ Izumi Chuma

chuizm@kobe-u.ac.jp

1 Graduate School of Agricultural Sceience, Kobe University, 1-1 Rokkodai-cho, Nada-ku, Kobe City 657-8501, Japan

2 Faculty of Agriculture, University of the Ryukyus, 1 Senbaru, Nishihara-cho, Nakagami-gun, Okinawa 903-0213, Japan
Keywords Fusarium solani species complex - Erythrina variegata $\cdot$ Sudden death $\cdot$ Quadrastichus erythrinae $\cdot$ Gall wasp · Okinawa $\cdot$ Japan

\section{Introduction}

The decline of Erythrina trees-abnormal defoliation, absence of flowering, and death-has been increasing in Japan and Taiwan (Uechi et al. 2007). Gall formation on leaves and petioles caused by the gall wasp Quadrastichus erythrinae Kim has been accepted as the cause of this syndrome and death (Rubinoff et al. 2010; Uechi et al. 2007). Infestation by this gall wasp, which is hypothesized to be native to Africa, began simultaneously during the 2000s in various areas of the world. The first report was from Taiwan in 2003 (Yang et al. 2004). In Japan, infestation was found in 2005 on an Indian coral tree, Erythrina variegata L., in Ishigaki Island, Okinawa Prefecture (Uechi et al. 2007). It was also found in Singapore (Kim et al. 2004), India (Faizal et al. 2006), Hawaii (Gramling 2005) and Florida in the United States (Reimer 2007), Vietnam (Uechi et al. 2007), China, the Philippines (Heu et al. 2008), and Brazil (Culik et al. 2014). To date, eight species and one subspecies among 110 Erythrina spp. have been reported as hosts.

Erythrina variegata, called "deigo" in Japanese, was introduced before the nineteenth century to the southern islands of Japan from India or Malaysia and has been commonly planted in parks and along the seashore and roadsides. Its wood is also used for traditional Ryukyu lacquerware. Injecting tree trunks with an insecticide (thiamethoxam, Izutsuya Chemical Industry) effectively kills larvae in the galls of $Q$. erythrinae (Kiyuna 2008); however, this technique did not decrease the mortality of E. variegata. Another species, E. crista-galli L., which is widely planted in the Honshu and Kyushu regions 
of Japan, is also under scrutiny. Due to these circumstances, a new strategy to protect Erythrina spp. is urgently needed.

Whether Q. erythrinae can directly kill trees is in question. In general, deciduous trees recover from unexpected defoliation by insects and seldom die from insect infestations. First, defoliation and the sudden death of host trees are disadvantageous to the propagation of $Q$. erythrinae. The sudden necrosis of bark tissue accompanied by an odor and the exfoliation of host trunks before death, when branches and twigs are still alive, suggest the activity of microorganisms in the lower part of the tree rather than trouble in the leaves. From a pathological perspective, Q. erythrinae may thus not be killing $E$. variegata. We obtained information that Erythrina death had occurred in Okinawa before 2005 without $Q$. erythrinae infestation, and the dead tree was processed as "cause unknown" (Y. Sakai, Okinawa Prefectural Government, personal communication). Unfortunately, there were no investigations on the relationship between $Q$. erythrinae infestation and symptom development in host trees. Previous reports on the mortality or wilt diseases of trees, such as Japanese oak wilt caused by Raffaelea quercivora (Kuroda 2001), fig wilt (fig canker) caused by Ceratocystis ficicola (Morita et al. 2016), and spruce wilt caused by C. polonica (Kuroda 2005), suggest that the contribution of microorganisms to Erythrina decline should also be checked. In preliminary investigations, Fusarium spp. were frequently isolated from the stems of declining but still living trees (Kihara et al. 2016). To develop techniques to protect Erythrina spp., we need to determine the specific cause of the decline and mortality of the hosts.

In the present investigation, we studied the physiology and pathology of living trees with defoliation to identify anomalies and determine the causal factors of $E$. variegata decline and mortality. The contribution of microbes to host mortality, physiological changes and internal symptoms such as the defense reaction of host cells (Hillis 1987), xylem dysfunction (Kuroda 2001; Morita et al. 2016), and the distribution of candidate microbes in the declining trees were also examined. Trees were then inoculated with candidate pathogens to confirm pathogenicity. In the case of large trees, an investigation of internal symptoms is very important because sometimes a time lag from infection to visible wilt conceals the real causal factor(s). This report includes preliminary information for quickly controlling Erythrina decline.

\section{Materials and methods}

\section{Sampling and macroscopic observations}

Erythrina variegata was sampled three times during 2014 and 2015 from trees 30 to $60 \mathrm{~cm}$ in diameter (Table 1). Heavily damaged trees were cut and harvested from the base, or the largest branches were cut from planted trees that were not permitted to be cut down from the base. Two trees were harvested on May 20, 2014, at the University of the Ryukyus, Nisihara-cho, Nakagami-gun, Okinawa Prefecture, Japan. Specimen R1 had sparse leaves and was judged to be close to death (Level 1, extensive damage). A harvested, thick branch was cut into three pieces and used for microscopy and the isolation of microorganisms. Specimen $\mathrm{R} 2$ retained more leaves than on $\mathrm{R} 1$, although it was abnormally defoliated (Level 2, moderate damage). On September 9, 2014, one tree, P1, with few leaves (Level 1) was harvested in the Okinawa Prefectural Peace Memorial Park, Itoman City, Okinawa Prefecture. A thick branch $3.7 \mathrm{~m}$ long was cut into five pieces (Table 2). In addition, four branches with abundant leaves (Level 2), R3-R6, were harvested at the University of the Ryukyus. Galls of $Q$. erythrinae were not found on specimen R3 but were found on the petioles of R4 and R5 and on the leaf surface of R6. On July 29, 2015, specimen P2, with few leaves (Level 1) but without bark exfoliation, and specimen P3, with abundant leaves (Level 2), were selected at Peace Memorial Park. After the dye injection experiment explained below, the main trunk of $\mathrm{P} 2$ and a thick branch of $\mathrm{P} 3$ were harvested.

Healthy trees without infestation of $Q$. erythrinae do not exist in the natural environment in Okinawa Prefecture. Therefore, seedlings grown in a greenhouse without infestation of Q. erythrinae were provided from Okinawa Prefectural Forest Resource Research Center as control specimens. Portions of the 10 seedlings provided on December 1, 2014, were used for microscopy and for isolating microorganisms (Table 2 C1-C3).

\section{Water conduction in xylem}

To check xylem sap ascent, a dye solution was injected into the trunks of declining but living trees P2 (Level 1) and P3 (Level 2) on July 29, 2015, at Peace Memorial Park. Two holes, each $5 \mathrm{~mm}$ in diameter and $3 \mathrm{~cm}$ deep, were drilled in each trunk. A silicone tube was inserted into each hole, and $1 \%(\mathrm{w} / \mathrm{v})$ aqueous acid fuchsin in a 1-L bottle was allowed to drip into the tree from 11 a.m. to 2 p.m. On a sunny day, dye solution will be automatically absorbed and water-conducting xylem dyed red in healthy trees. This technique is convenient for detecting the activity of xylem conduction visually and from the amount of absorbed liquid (Kuroda and Yamada 1996). The trunk and branch were cut from the base into 30 - to $50-\mathrm{cm}$-long pieces so that stained areas on the cut surfaces could be observed by eye. Then the specimens were used for histological and pathological experiments. 
Table 1 Sampling and experiments with declining Erythrina variegata trees

\begin{tabular}{|c|c|c|c|c|c|c|c|c|}
\hline Sampling date & Tree no. & Sampling site & $\begin{array}{l}\text { Tree height } \\
\text { (m) }\end{array}$ & $\begin{array}{l}\text { Diameter at } \\
\text { breast height } \\
(\mathrm{cm})\end{array}$ & $\begin{array}{l}\text { Diameter of } \\
\text { specimen } \\
(\mathrm{cm})\end{array}$ & $\begin{array}{l}\text { Leaf } \\
\text { quantity } \\
\text { level* }\end{array}$ & $\begin{array}{l}\text { Condition, sam- } \\
\text { pled part }\end{array}$ & $\begin{array}{l}\text { Experimental } \\
\text { purpose }\end{array}$ \\
\hline \multirow[t]{2}{*}{ May 20, 2014} & $\mathrm{R} 1$ & \multirow{2}{*}{$\begin{array}{l}\text { Univ. Ryukyus } \\
\text { Nisihara-cho, } \\
\text { Nakagami-gun }\end{array}$} & 7.9 & 45.2 & 20.0 & 1 & $\begin{array}{l}\text { Heavy damage, } \\
\text { thick branch }\end{array}$ & \multirow[t]{2}{*}{$\begin{array}{l}\text { Histology } \\
\text { Fungal isolation }\end{array}$} \\
\hline & $\mathrm{R} 2$ & & 8.7 & 44.8 & 8.0 & 2 & $\begin{array}{l}\text { Slight damage, } \\
\text { thick branch } \\
\text { 26-years-old }\end{array}$ & \\
\hline \multirow[t]{5}{*}{ Sept. 9, 2014} & $\mathrm{P} 1$ & $\begin{array}{l}\text { Okinawa Pre- } \\
\text { fectural Peace } \\
\text { Memorial Park, } \\
\text { Itoman City }\end{array}$ & 7.8 & 58.6 & 29.0 & 1 & $\begin{array}{l}\text { Heavy damage, } \\
\text { thick branch }\end{array}$ & $\begin{array}{l}\text { Histology } \\
\text { Fungal isolation }\end{array}$ \\
\hline & R3 & \multirow[t]{4}{*}{ Univ. Ryukyus } & 10.0 & 59.2 & 7.0 & 2 & $\begin{array}{l}\text { No galls, } \\
\text { upper branch }\end{array}$ & Fungal isolation \\
\hline & R4 & & 5.7 & 31.1 & 5.0 & 2 & $\begin{array}{l}\text { Galls on petioles, } \\
\text { upper branch }\end{array}$ & $\begin{array}{l}\text { Histology } \\
\text { Fungal isolation }\end{array}$ \\
\hline & R5 & & 5.3 & 32.9 & 3.0 & 2 & $\begin{array}{l}\text { Galls on petioles, } \\
\text { upper branch }\end{array}$ & $\begin{array}{l}\text { Histology } \\
\text { Fungal isolation }\end{array}$ \\
\hline & R6 & & - & - & 1.5 & 2 & $\begin{array}{l}\text { Galls on leaves, } \\
\text { upper branch }\end{array}$ & Fungal isolation \\
\hline \multirow[t]{2}{*}{ July 29, 2015} & $\mathrm{P} 2$ & \multirow[t]{2}{*}{$\begin{array}{l}\text { Peace Memorial } \\
\text { Park }\end{array}$} & 5.2 & 48.1 & - & 1 & $\begin{array}{l}\text { Heavy damage, } \\
\text { hole tree }\end{array}$ & $\begin{array}{l}\text { Water conduction } \\
\text { Histology } \\
\text { Fungal isolation }\end{array}$ \\
\hline & P3 & & 6.4 & 48.4 & - & 2 & $\begin{array}{l}\text { Slight damage, } \\
\text { thick branch }\end{array}$ & $\begin{array}{l}\text { Water conduction } \\
\text { Histology } \\
\text { Fungal isolation }\end{array}$ \\
\hline \multirow[t]{3}{*}{ Dec. 1, 2014} & $\mathrm{C} 1$ & \multirow{3}{*}{$\begin{array}{l}\text { Okinawa Pref. } \\
\text { Forest Resource } \\
\text { Research } \\
\text { Center }\end{array}$} & 0.20 & - & 0.5 & 3 & \multirow{3}{*}{$\begin{array}{l}\text { No damage, } \\
\text { potted seedlings } \\
1 \text { year old }\end{array}$} & \multirow{3}{*}{$\begin{array}{l}\text { Histology } \\
\text { Fungal isolation }\end{array}$} \\
\hline & $\mathrm{C} 2$ & & 0.25 & - & 0.5 & 3 & & \\
\hline & $\mathrm{C} 3$ & & 0.24 & - & 0.5 & 3 & & \\
\hline
\end{tabular}

Level 1 small quantity of leaves, Level 2 abundant leaves, Level 3 healthy condition

\section{Macro- and microscopic observations}

Specimens were dissected into smaller pieces, and the cross-section and radial surfaces were observed with a stereoscopic microscope (SMZ1500, Nikon, Tokyo, Japan) and photographed with digital cameras. Specifically, the phloem and xylem of slightly damaged trees (Level 2) were compared with those of severely damaged trees (Level 1).

Next, specimens were processed for light microscopy. Some of the specimens were cut into small blocks $(1 \times 1 \times 2$ to $2 \times 2 \times 3 \mathrm{~cm}$ ) that contained lesions or discoloration; these were fixed in FAA (formalin, acetic acid, 50\% ethyl alcohol; 5:5:90, v/v) for 1 week and, subsequently, washed for 1 day under tap water. With a sliding microtome (Ritratome REM-710, Yamato Koki Co., Asaka, Saitama, Japan), 20to 30- $\mu \mathrm{m}$-thick sections (transverse, tangential, and radial) were cut from the small blocks. Parts of the sections were mounted onto slides without staining to observe the natural colors and cytological changes. Some sections were stained with safranin-fast green for the observation of lignified xylem cells and cell contents (Ruzin 1999). For the observation of fungal hyphae, parts of the sections were stained with periodic acid-Schiff (PAS) and toluidine blue O (Feder and O'Brien 1968). Microscopic observation (ECLIPSE 80i, ECLIPSE Ni-U, Nikon) was focused on the range of discolored xylem, the distribution of fungal hyphae, and the necrosis of parenchyma cells.

\section{Fungal isolation and identification}

Specimens were cut from various parts of declining trees. In addition to abnormally discolored and necrotic phloem tissues, nondiscolored xylem and living phloem were examined for the presence of fungi (Table 2). In large diseased trees, the fungus is sometimes restricted to one part of the tree body. For instance, specimen R1 at the base of a branch contained discolored and nondiscolored xylem at the same height. Tissues were dissected into $1 \times 3 \times 5 \mathrm{~mm}$ cubes with disposable knife blades. Tissue cubes were washed with $70 \%$ ethanol and the surface was sterilized with aqueous sodium hypochlorite solution (effective chlorine concentration $0.5 \%$ ), placed on potato dextrose agar (PDA, Difco) in $9-\mathrm{cm}$ petri dishes, and incubated at $25^{\circ} \mathrm{C}$. In addition, 
Table 2 Tissue condition in declining Erythrina variegata trees and healthy or inoculated seedlings, and fungi detected

\begin{tabular}{|c|c|c|c|c|c|c|c|c|}
\hline \multirow[t]{2}{*}{ Tree no. } & \multirow[t]{2}{*}{ Part examined } & \multirow{2}{*}{$\begin{array}{l}\text { Xylem } \\
\text { discolored }^{\text {a }}\end{array}$} & \multirow{2}{*}{$\begin{array}{l}\text { Phloem } \\
\text { necrosis }^{\mathrm{a}}\end{array}$} & \multirow{2}{*}{ Cultured part } & \multirow{2}{*}{$\begin{array}{l}\text { No. of } \\
\text { pieces } \\
\text { cultured }\end{array}$} & \multicolumn{2}{|c|}{ Fusarium isolate tested } & \multirow{2}{*}{$\begin{array}{l}\text { Other fungi } \\
\text { isolated }^{\mathrm{d}}\end{array}$} \\
\hline & & & & & & Isolate $^{b}$ & Species $^{c}$ & \\
\hline \multirow[t]{4}{*}{ R1 } & Top of branch & - & - & $\begin{array}{l}\text { Nondiscolored } \\
\text { xylem } \\
\text { Living phloem }\end{array}$ & 42 & R1-TB3 & + & $\begin{array}{l}\text { Alternaria sp. } .^{\mathrm{e}} \\
\text { Papularia sp. }\end{array}$ \\
\hline & Middle of branch & + & + & Discolored xylem & 14 & R1-MA7 & + & Papularia sp. ${ }^{\mathrm{e}}$ \\
\hline & Base of branch & + & + & Discolored xylem & 63 & R1-BC6 & FSSC Strain $B^{f}$ & + \\
\hline & & & & $\begin{array}{l}\text { Nondiscolored } \\
\text { xylem }\end{array}$ & 21 & - & - & Papularia sp. $^{\mathrm{e}}$ \\
\hline R2 & Branch & - & - & $\begin{array}{l}\text { Nondiscolored } \\
\text { xylem }\end{array}$ & 42 & - & - & $\begin{array}{l}\text { Papularia sp. }{ }^{\mathrm{e}} \\
\text { Pestalotia } \text { sp. }^{\mathrm{e}}\end{array}$ \\
\hline \multirow[t]{8}{*}{ P1 } & $\begin{array}{l}\text { Top of branch: } \\
195 \mathrm{~cm} \text { from }\end{array}$ & - & + & $\begin{array}{l}\text { Nondiscolored } \\
\text { xylem }\end{array}$ & 63 & P1-160OA7 & FSSC Strain $A^{g}$ & - \\
\hline & base & & & Necrotic phloem & 21 & P1-195PA1 & + & - \\
\hline & $90 \mathrm{~cm}$ from base & + & + & Discolored xylem & 21 & P1-90IB1 & + & - \\
\hline & & & & $\begin{array}{l}\text { Nondiscolored } \\
\text { xylem }\end{array}$ & 21 & P1-90OA1 & + & - \\
\hline & & & & Necrotic phloem & 21 & P1-90PA7 & + & Papularia sp. ${ }^{\mathrm{e}}$ \\
\hline & $30 \mathrm{~cm}$ from base & + & + & Discolored xylem & 21 & - & - & Papularia sp. $^{\mathrm{e}}$ \\
\hline & & & & $\begin{array}{l}\text { Nondiscolored } \\
\text { xylem }\end{array}$ & 21 & P1-30OA1 & + & + \\
\hline & & & & Necrotic phloem & 21 & P1-30PA1 & + & - \\
\hline \multirow[t]{2}{*}{ R3 } & Upper branch & - & - & $\begin{array}{l}\text { Nondiscolored } \\
\text { xylem } \\
\text { Living phloem }\end{array}$ & 42 & R3-2XA1 & + & + \\
\hline & & & & Petiole & 10 & R3-1LA1 & + & + \\
\hline R4 & Upper branch & - & - & $\begin{array}{l}\text { Nondiscolored } \\
\text { xylem } \\
\text { Living phloem }\end{array}$ & 42 & R4-1PC6 & + & Nigrospora sp. ${ }^{\mathrm{e}},+$ \\
\hline \multirow[t]{2}{*}{ R5 } & Upper branch & - & - & $\begin{array}{l}\text { Nondiscolored } \\
\text { xylem } \\
\text { Living phloem }\end{array}$ & 21 & R5-1MA1 & + & - \\
\hline & & & & Petiole & 10 & R5-2LA5 & + & - \\
\hline \multirow[t]{2}{*}{ R6 } & Upper branch & - & - & $\begin{array}{l}\text { Nondiscolored } \\
\text { xylem Living } \\
\text { phloem }\end{array}$ & 42 & R6-SA1 & + & - \\
\hline & & & & Living petiole & 21 & - & - & Colletotrichum sp. ${ }^{\mathrm{g}}$ \\
\hline \multirow[t]{8}{*}{$\mathrm{P} 2^{\mathrm{h}}$} & a: Branch & + & + & Discolored xylem & 6 & P2-a11 & + & - \\
\hline & b: Branch & + & + & Discolored xylem & 6 & P2-b11 & + & Lasiodiplodia sp. ${ }^{\mathrm{g}}$ \\
\hline & c: Branch & + & + & Discolored xylem & 6 & P2-c22 & FSSC Strain $A^{g}$ & - \\
\hline & d: Branch & + & + & Discolored xylem & 6 & P2-d11 & FSSC Strain $A^{g}$ & Lasiodiplodia sp..$^{\mathrm{g}}$ \\
\hline & e: Base of branch & + & - & Discolored xylem & 6 & P2-e12 & FSSC Strain $\mathrm{A}^{\mathrm{g}}$ & - \\
\hline & f: Lower trunk & + & + & $\begin{array}{l}\text { Whitish hyphae on } \\
\text { cross-cut surface }\end{array}$ & 2 & $\begin{array}{l}\text { P2-f22 } \\
\quad \text { (LC198904) }\end{array}$ & FSSC Strain $B^{f}$ & + \\
\hline & & & & Discolored xylem & 8 & $\begin{array}{l}\text { P2-f11 } \\
\text { (LC198903, } \\
\text { LC198905, } \\
\text { LC198906, } \\
\text { LC198907), } \\
\text { P2-fK }\end{array}$ & FSSC Strain $A^{g}$ & + \\
\hline & $\mathrm{g}$ : Base of trunk & + & + & Discolored xylem & 6 & P2-g21 & FSSC Strain $B^{f}$ & - \\
\hline
\end{tabular}


Table 2 (continued)

\begin{tabular}{|c|c|c|c|c|c|c|c|c|}
\hline \multirow[t]{2}{*}{ Tree no. } & \multirow[t]{2}{*}{ Part examined } & \multirow{2}{*}{$\begin{array}{l}\text { Xylem } \\
\text { discolored }^{\mathrm{a}}\end{array}$} & \multirow{2}{*}{$\begin{array}{l}\text { Phloem } \\
\text { necrosis }^{\mathrm{a}}\end{array}$} & \multirow{2}{*}{ Cultured part } & \multirow{2}{*}{$\begin{array}{l}\text { No. of } \\
\text { pieces } \\
\text { cultured }\end{array}$} & \multicolumn{2}{|c|}{ Fusarium isolate tested } & \multirow{2}{*}{$\begin{array}{l}\text { Other fungi } \\
\text { isolated }^{\mathrm{d}}\end{array}$} \\
\hline & & & & & & Isolate $^{\mathrm{b}}$ & Species $^{\mathrm{c}}$ & \\
\hline \multirow[t]{2}{*}{$\mathrm{P} 3^{\mathrm{h}}$} & h: Top of branch & - & - & $\begin{array}{l}\text { Nondiscolored } \\
\text { xylem, living } \\
\text { phloem }\end{array}$ & 6 & P3-h11 & + & Lasiodiplodia sp. $^{\mathrm{e}}$ \\
\hline & i: Base of branch & + & - & $\begin{array}{l}\text { Discolored xylem, } \\
\text { living phloem }\end{array}$ & 6 & P3-i11 & FSSC Strain $B^{f}$ & - \\
\hline \multirow[t]{2}{*}{$\mathrm{C} 1$} & Stem & - & - & $\begin{array}{l}\text { Nondiscolored } \\
\text { xylem, living } \\
\text { phloem }\end{array}$ & 21 & - & - & - \\
\hline & Petiole & - & - & Petiole & 21 & - & - & - \\
\hline \multirow[t]{2}{*}{$\mathrm{C} 2$} & Stem & - & - & $\begin{array}{l}\text { Nondiscolored } \\
\text { xylem, living } \\
\text { phloem }\end{array}$ & 21 & - & - & - \\
\hline & Petiole & - & - & Petiole & 21 & - & - & $\begin{array}{l}\text { Plectosphaerella } \\
\text { sp. } . \mathrm{g}\end{array}$ \\
\hline \multirow[t]{2}{*}{ C3 } & Stem & - & - & $\begin{array}{l}\text { Nondiscolored } \\
\text { xylem Living } \\
\text { phloem }\end{array}$ & 21 & - & - & - \\
\hline & Petiole & - & - & Petiole & 21 & - & - & + \\
\hline \multirow[t]{3}{*}{$\mathrm{AB} 2^{\mathrm{i}}$} & Stem & - & + & $\begin{array}{l}\text { Whitish hyphae on } \\
\text { bark surface }\end{array}$ & 2 & $\mathrm{AB} 2-\mathrm{S} 1$ & FSSC Strain $A^{g}$ & - \\
\hline & & & & Xylem, phloem & 9 & AB2-L3 & FSSC Strain $B^{f}$ & - \\
\hline & Root & - & - & Xylem, phloem & 3 & AB2-R1 & FSSC Strain $B^{f}$ & - \\
\hline \multirow[t]{2}{*}{$\mathrm{A} 2^{\mathrm{i}}$} & Stem & - & - & Xylem, phloem & 9 & - & - & Myrothecium sp. ${ }^{\mathrm{g}}$ \\
\hline & Root & - & - & Xylem, phloem & 3 & $\begin{array}{l}\text { A2-R2 } \\
\text { A2-R3 }\end{array}$ & $\begin{array}{l}\text { FSSC Strain } A^{g} \\
\text { FSSC Strain } B^{f}\end{array}$ & - \\
\hline \multirow[t]{2}{*}{$\mathrm{Ct} 2^{\mathrm{i}}$} & Stem & - & - & Xylem, phloem & 9 & - & + & + \\
\hline & Root & - & - & Xylem, phloem & 3 & - & + & + \\
\hline
\end{tabular}

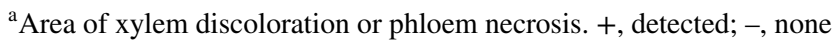

${ }^{\mathrm{b}} \mathrm{EMBL} / \mathrm{GenBank}$ accessions for nucleotide sequences are in parentheses

${ }^{c}$ FSSC, Fusarium solani species complex; +, Fusarium sp. identified by conidial morphology; -, no fungus detected

$\mathrm{d}_{+}$, Fungus isolated, genus not identified; -, no fungus detected

${ }^{\mathrm{e}} \mathrm{Genera}$ identified by conidial morphology

${ }^{\mathrm{f}}$ Strain B, ITS nucleotide sequence was $99.8 \%$ (547/548 nt) identical to strain A

${ }^{\mathrm{g}}$ Genera identified by conidial morphology and ITS sequence

${ }^{\text {h}}$ Letter codes $\mathrm{a}-\mathrm{i}$ correspond to those in Fig. 1

${ }^{\mathrm{i}}$ Inoculated seedlings. AB2, inoculated with P2-f11 and P2-f22; A2, inoculated with P2-f11; Ct2, no inoculation

hyphae that formed on the cut surface of some specimens within 5 days of the harvest date were picked with a lancet and incubated on PDA as above. Petioles of E. variegata obtained from trees R3, R5, and R6 were also sterilized and incubated as trunk tissue sections for detecting the site of infection. Control specimens cut from seedlings without $Q$. erythrinae infestation were also incubated on PDA. Spores formed on PDA were identified with a light microscope (Barnett and Hunter 1998). Strains that were predominantly isolated from declining trees were judged to be potential pathogens.

To identify species of the predominant isolates (Table 2), DNA sequencing of the nu-rRNA gene repeat (rDNA-ITS), a portion of RNA polymerase II (RPB2), encoding the second largest subunit of RNA polymerase, and the translation elongation factor $(E F-1 a)$ gene was conducted as follows. Mycelial cultures grown on PDA were suspended in $100 \mu \mathrm{L}$ of Tris-EDTA (TE) buffer, incubated at $95^{\circ} \mathrm{C}$ for $10 \mathrm{~min}$, and used as a PCR template. The rDNA-ITS was amplified with the primers ITS5 (5'-GGAAGTAAAAGT CGTAACAAGG-3') and ITS4 (5'-TCCTCCGCTTATTGA TATGC-3') (White et al. 1990), RPB2 was amplified with primers $7 \mathrm{cF}\left(5^{\prime}\right.$-ATGGGYAARCAAGCYATGGG-3') and $11 \mathrm{aR}$ (5'-GCRTGGATCTTRTCRTCSACC-3') (O'Donnell et al. 2007) and primers 5F2 (5'-GGGGWGAYCAGAAG AAGGC-3') and 7cR (5'-CCCATRGCTTGYTTRCCCAT-3') 
(O'Donnell et al. 2007), and EF- $1 a$ was amplified with primers EF-1H (5'-ATGGGTAAGGAAGACAAGAC-3') and EF-2T (5'-GGAAGTACCAGTGATCATGTT-3') (O'Donnell 2000) in a 20- $\mu \mathrm{L}$ reaction of KOD FX Neo DNA polymerase (TOYOBO, Osaka, Japan). Sequence data for strains A and B are available in the EMBL/GenBank databases, with accession numbers listed in Table 2 . We used the sequence data of $F$. staphyleae and 30 FSSC strains reported by Costa et al. (2016), Kasson et al. (2013), O’Donnell et al. (2008, 2015) and Zhang et al. (2006), which were obtained from GenBank for multiple sequence alignment using CLUSTAL W and analysis by MEGA7 (Kumar et al. 2016). The phylogenetic relationship was inferred by using the maximum likelihood method based on the Jukes-Cantor model (Jukes and Cantor 1969). All positions containing gaps and missing data were eliminated. Nodal supports were assessed using 1000 bootstrap replicates. The tree was rooted using $F$. staphyleae as an outgroup.

\section{Inoculation experiments}

Three inoculation experiments, including the preliminary one were done. Three seedlings were used for the preliminary experiment, and 8 and 11 seedlings were used for the main experiments, conducted twice (Table 3). Although inoculation experiments for tree diseases usually use 20-50 seedlings (Morita et al. 2016), fewer seedlings were used in the present experiments because seedlings of E. variegata are difficult to prepare since flowering and seed formation are rare in the Ryuku Islands. Twenty-two seedlings were provided by the Okinawa Prefectural Forest Resource Research Center on August 5, 2015, and 20 seedlings were provided by Ryukyu Sankei Co., Ltd., on June 2, 2016.

Inoculation schedules and specimen conditions are detailed in Table 3. In the preliminary experiment, a mycelial disk of three strains cultured for 2 weeks on PDA was placed onto a wound made at the base of seedlings (height ca. $30 \mathrm{~cm}$ ) or petioles to narrow the number of candidates. Seedlings were observed for symptoms for 2 months. Two strains were chosen for the second inoculation experiment in 2015, and one of them was used for the third experiment in 2016.

The second experiment with 8 seedlings (height ca. $30 \mathrm{~cm}$ ) was conducted on October 2, 2015. Soil was washed from the roots of seedlings under tap water. Then the seedlings were cultured in $200 \mathrm{~mL}$ of distilled water after their roots were cut to lengths of $6 \mathrm{~cm}$. As inocula, spores of strain A (P2-f11) and strain B (P2-f22) were incubated on the PDA. Spores $\left(1 \times 10^{5} / \mathrm{mL}\right)$ of strains A, $\mathrm{B}$, or $\mathrm{A}+\mathrm{B}$ were added to two pots of water-cultured seedlings. Two more seedlings were cultured without fungal spores as controls. Symptom development was observed for 2 months in an incubator set at $25^{\circ} \mathrm{C}$. Tissue of dead seedlings was used for reisolation.

In the third experiment, 11 seedlings were inoculated with strain A (P2-f11) on July 20, 2016 (Table 3). Mycelia incubated on sterilized toothpicks with PDA were placed in four small holes at the base of the lower stems of $E$. variegata seedlings.

Symptom development was checked every day or at 2-day intervals for 7-10 weeks. Death of specimens was judged as complete defoliation with no new leaves forming at the top or on the stem of seedlings. Tissue of dead seedlings was used for reisolations.

\section{Results}

\section{Macroscopic characteristics of declining trees}

Heavily damaged and almost defoliated E. variegata trees were commonly found adjacent to dead trees at both harvest sites at the University of the Ryukyus and Peace Memorial Park. Information from the local government of Okinawa Prefecture stated that the decline of trees was progressing outward from the center of a group of dead trees in Peace Memorial Park (Y. Sakai, Okinawa Prefectural Government, personal communication).

On the cut surface of the trunks and branches of heavily damaged and mostly defoliated specimens-R1, P1, and P2 (Level 1, Table 1; Fig. 1a) - pale brown or gray discolored xylem was visible (Fig. 2a, Dis: inside the dotted line). The discolored area was wider in the lower trunk of P2 (Fig. 2a, $82 \%$ of cross section) and in the lower part of a thick branch of R1. The bark of these trees, R1 and $\mathrm{P} 1$, was soft at various parts of the trunks and oozed liquid when pressed with fingertips. Necrotic phloem tissue in the softened area (Fig. 2, Nec) formed adjacent to the grayish discoloration in the xylem (Fig. 2a, Dis). A putrid smell was detected from the necrotic, softened tissue, and the necrotic bark tissue had exfoliated from the trunk surface. In trees with abundant leaves (Level 2, Table 1; Fig. 2b), branches of R2-R6, and the trunk of P3, discoloration and necrosis were not observed in the trunk tissue (Table 2).

\section{Histological anomalies of declining trees}

\section{Changes in host cells and distribution of fungal hyphae}

In the discolored xylem of heavily damaged trees- $\mathrm{R} 1$, P1, and P2 (Figs. 2a, 3a, 4a) - yellow to brown substances had accumulated in parenchyma cells and in the lumen of vessels (Fig. 3c), and the cell wall of the wood fibers 
Table 3 Inoculation experiments with healthy seedlings of Erythrina variegata

\begin{tabular}{|c|c|c|c|c|c|}
\hline Inoculation and harvest date (duration) & Specimen no. & Source of seedlings & Height $(\mathrm{cm})$ & Diameter $(\mathrm{cm})$ & Inoculation site \\
\hline $\begin{array}{l}\text { Preliminary July } 21 \text { to Sept. 10, } 2015 \\
\text { (58 days) }\end{array}$ & $\begin{array}{l}\text { L1 } \\
\text { L2 } \\
\text { L3 } \\
\text { S1 } \\
\text { S2 } \\
\text { S3 } \\
\text { S4 }\end{array}$ & $\begin{array}{l}\text { Okinawa Pref. Forest Resource } \\
\text { Research Center }\end{array}$ & $26-41$ & $0.6-0.8$ & $\begin{array}{l}\text { Petiole } \\
\text { Petiole } \\
\text { Petiole } \\
\text { Stem } \\
\text { Stem } \\
\text { Stem } \\
\text { Stem }\end{array}$ \\
\hline Oct. 2 to Nov. 17, 2015 (46 days) & $\begin{array}{l}\mathrm{AB} 1^{\mathrm{a}} \\
\mathrm{AB} 2 \\
\mathrm{~A} 1 \\
\mathrm{~A} 2 \\
\mathrm{~B} 1 \\
\mathrm{~B} 2 \\
\mathrm{Ct} 1 \\
\mathrm{Ct} 2\end{array}$ & $\begin{array}{l}\text { Okinawa Pref. Forest Resource } \\
\text { Research Center }\end{array}$ & $17-25$ & $0.4-0.7$ & Roots \\
\hline July 20 to Sept 28, 2016 (70 days) & $\begin{array}{l}1 \\
2 \\
3 \\
4 \\
5 \\
6 \\
7 \\
8 \\
9 \\
\mathrm{Ct} 1 \\
\mathrm{Ct} 2\end{array}$ & Ryukyu Sankei Co., Ltd & $21-54$ & $0.7-1.5$ & Lower stem \\
\hline
\end{tabular}

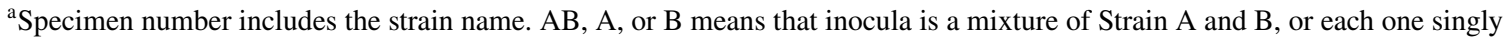

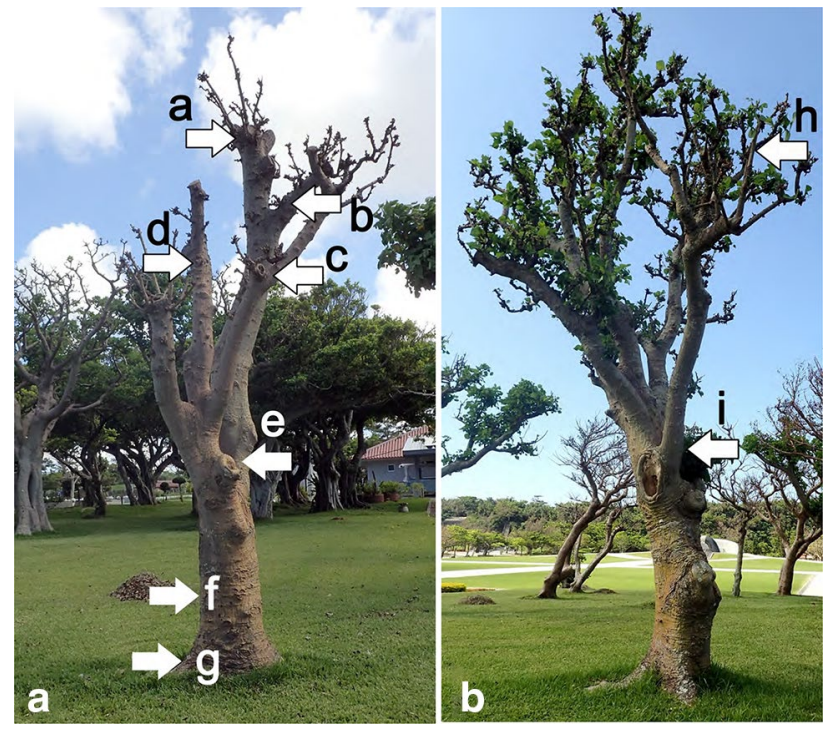

Fig. 1 Condition of declining Erythrina variegata trees harvested at Peace Memorial Park in Itoman City, Okinawa Prefecture, on July 29, 2015. a Heavily damaged tree (P2). b Slightly damaged tree (P3). Arrows $a-i$ sampling for histology and fungal isolation was also stained. Fungal hyphae were observed in the discolored xylem area, vessels, axial parenchyma, wood fibers, and ray parenchyma tissues (Fig. 3b). Hyphae were abundant on the xylem side of the cambial region where the xylem discoloration had expanded and reached the cambium (Fig. 2a, Nec). Pale yellow substances were observed in some vessels and axial parenchyma of heavily damaged specimen P2 where slight discoloration was detected or indistinct by eye (Fig. 1a: c-e); hyphae were rarely found in such areas. In the cortex, mucilage ducts were filled with exudates.

In slightly deteriorated trees (abundant leaves, Level 2), R2-R5 and P3, no colored substances or hyphae were observed in the xylem. However, tyloses and oily substances were apparent in vessels and likely causing at least partial dysfunction of the vessels.

\section{Leaves and petioles with galls of Q. erythrinae}

When the histology of petioles with galls (R5) were compared with petioles without galls (R3) (Fig. 5), the 


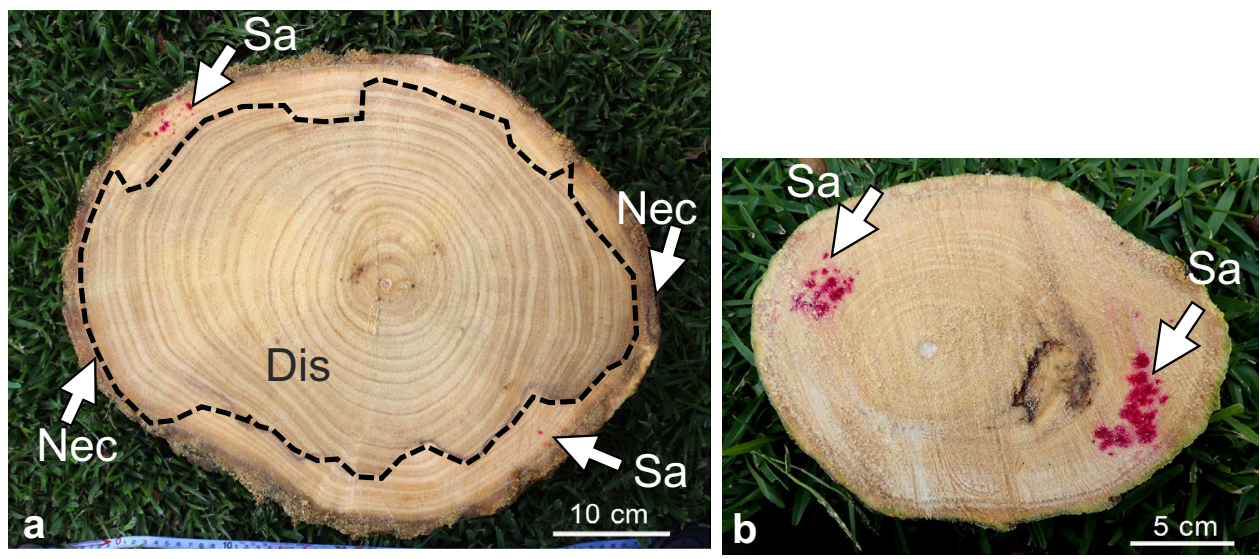

Fig. 2 Discoloration and dysfunction of xylem in the trunks of declining E. variegata trees harvested on July 29, 2015. a Wide xylem discoloration (Dis: inside the dotted line), necrosis of phloem and cambium $(\mathrm{Nec})$, and extensive decrease of sap ascent $(\mathrm{Sa})$ in the
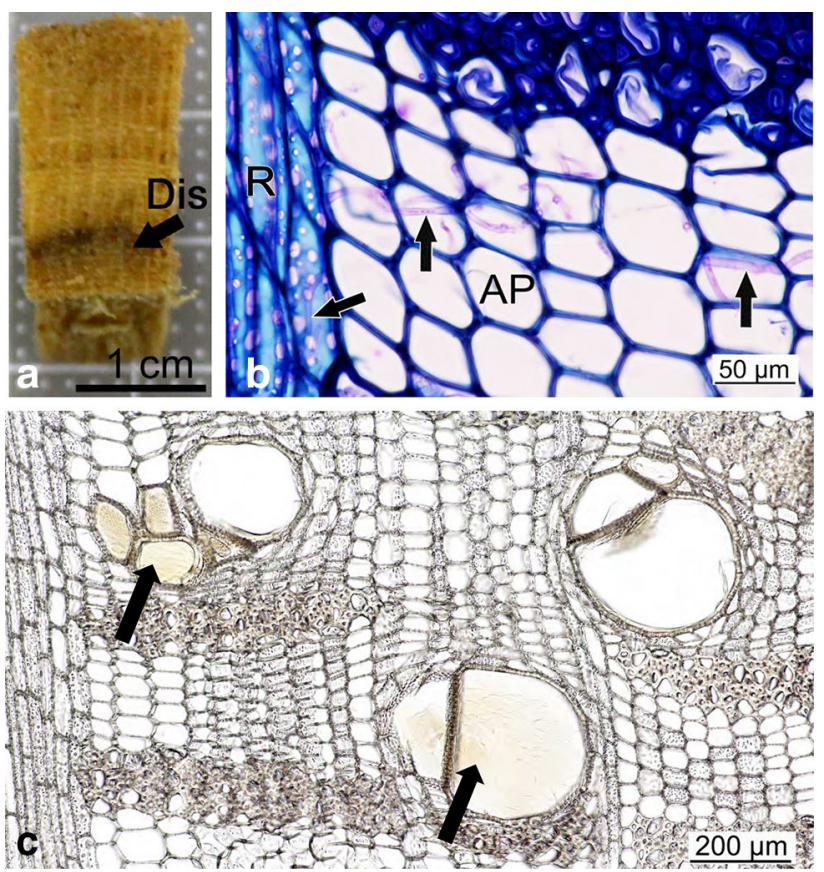

Fig. 3 Colored substances and hyphae in discolored xylem of declining E. variegata in cross sections observed with light microscope. a Cross-cut surface of discolored xylem (Dis) in branch. b Hyphae (arrows) in ray tissue (R) and axial parenchyma cells (AP) of discolored area. c Pale-brown secondary metabolites, synthesized as a defense reaction to infection and filled in vessels (arrows). Section $\mathbf{b}$ was stained with toluidine blue $\mathrm{O}$; section $\mathbf{c}$ was not stained

boundaries of the xylem, phloem, and cortex were distinct in the petioles of R3 (Fig. 5b). In contrast, in R5 tissue, numerous parenchymatous cells were abnormal and in disorderly arrangements, and the boundaries of the cortex and other heavily damaged tree (Fig. 1a, specimen P2). b Moderate sap ascent (arrows) in the slightly damaged tree (Fig. 1b, specimen P3). Water conduction was tested by the absorption of acid fuchsin solution for $3 \mathrm{~h}$ before the tree was cut down

tissues were not distinguishable (Fig. 5c). No fungal hyphae or discolored host cells was observed around the galls.

\section{Distribution and identity of fungi}

\section{In trunks and branches}

Fusarium-type conidia with white to pale yellow mycelia (Table 2; Fig. 4) were identified from the predominant fungi isolated from various parts of declining trees. Other fungi such as the Papularia sp., Pestalotia sp., and Alternaria sp. were isolated from necrotic tissue at lower frequency. We did not attempt to identify fungi that were isolated at very low frequency (Table 2: Fungal isolation + ).

A comparison of the rDNA-ITS region of eight Fusarium isolates from trees $\mathrm{P} 2$ and $\mathrm{P} 3$ revealed two patterns for the nucleotide sequences with only one nucleotide substitution (Table 2). One of the eight samples derived from whitish mycelia that grew from the surface of the discolored xylem severely damaged tree P2 (P2-fK, Table 2; Fig. 4a). Nucleotide sequence analysis of the ITS, the RPB2, and the $E F-1 a$ of representative isolate $\mathrm{P} 2$-f11 (strain A) indicated that strain A belongs to F. solani species complex (FSSC) clade 3 defined by O'Donnell et al. (2008). Figure 6 shows the phylogenetic tree inferred from the nucleotide sequences of EF-1a using 29 Fusarium strains and strain A. Strain A was adjacent to Clade B of the Ambrosia Fusarium clade (AFC), known as a group of symbionts of ambrosia beetles (Kasson et al. 2013; O'Donnell et al. 2015), and with $F$. pseudensiforme strains NRRL 46517 and FRC S1834, which are members of Clade A of the AFC (Kasson et al. 2013). Fungi belonging to the FSSC were not detected in the nondiscolored xylem (Table 2). 
Fig. 4 Fusarium sp. isolated from declining $E$. variegata. a-1 Whitish fungal hyphae on cross-cut surface of E. variegata trunk. a-2 Enlarged image of the boxed region in $\mathbf{a}-\mathbf{1}$. $\mathbf{b}$ Strain A (P2-f11). c Strain B (P2-g21). d Conidia of $\mathrm{P} 2$-f11. e Conidia of P2-g21
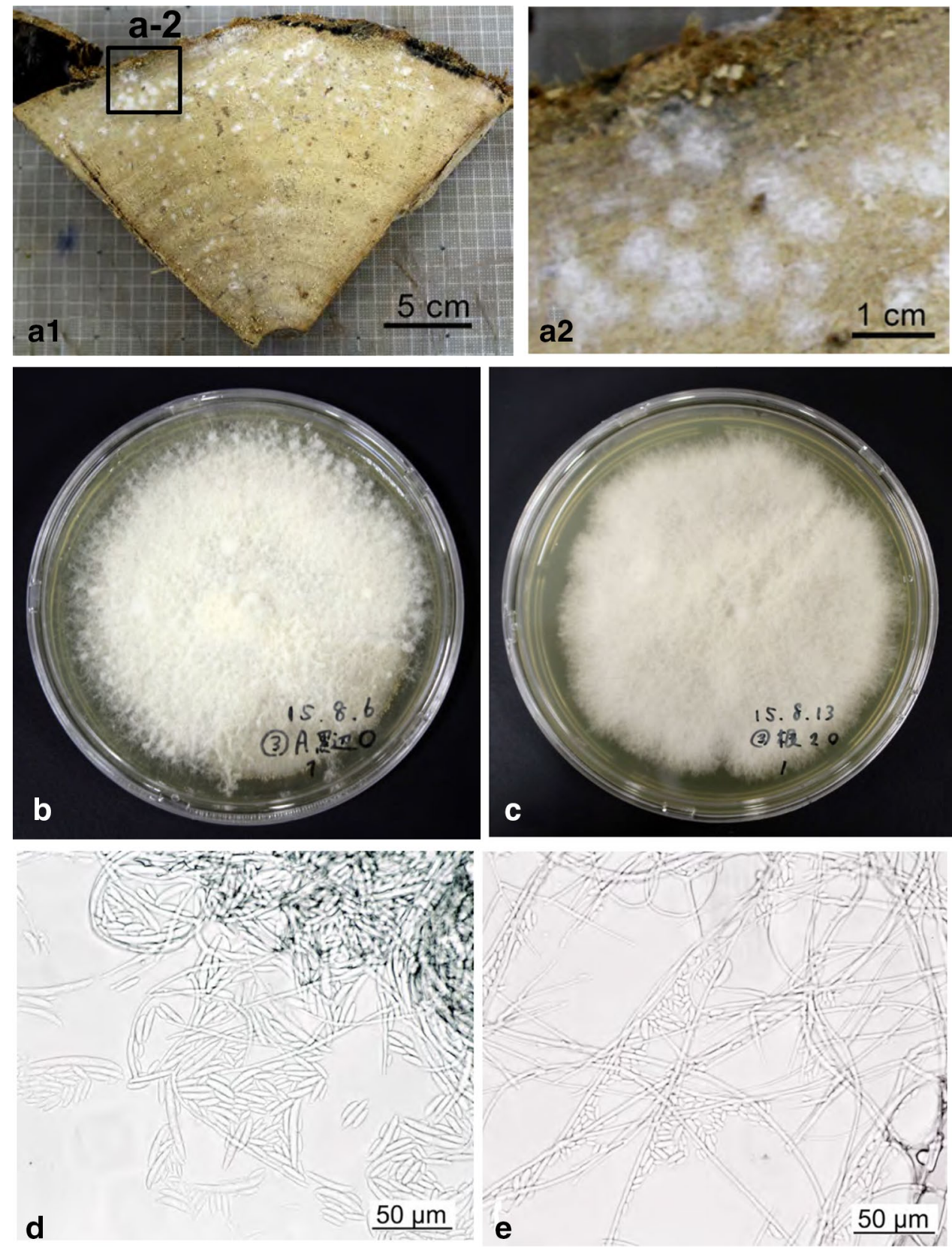

Quadrastichus erythrinae and fungi in leaves and petioles

Larvae of Q. erythrinae were found in galls on the leaves or petioles of specimens R4-R6 (with abundant leaves, Level 2). Fusarium spp. were isolated from some petioles of R3, R5, and R6, including normal leaves of R3 without galls.

\section{Fungal distribution in controls without Q. erythrinae infestation}

No fungi were isolated from the stems, and no Fusarium spp. were isolated from the petioles of control seedlings, C1-C3 (Table 2).

\section{Xylem dysfunction of host trees tested by dye injection}

In the heavily damaged tree $\mathrm{P} 2$, absorption of the dye solution through vessels was only $6.3 \mathrm{~mL} / \mathrm{h}$. A very narrow area was stained with the dye (Fig. $2 \mathrm{a}, \mathrm{Sa}$ ), since water conduction had almost ceased in the trunk by the time of the experiment. In contrast, tree P3, with abundant leaves, absorbed the dye solution at $15 \mathrm{~mL} / \mathrm{h}$, and the area with stained xylem was broader than that of P2 (Fig. 2b, $\mathrm{Sa})$. These results demonstrated that water conduction in the trunk of P3 was better than in P2. However, most leaves had drooped on tree $\mathrm{P} 3$ by around 2 p.m., when 


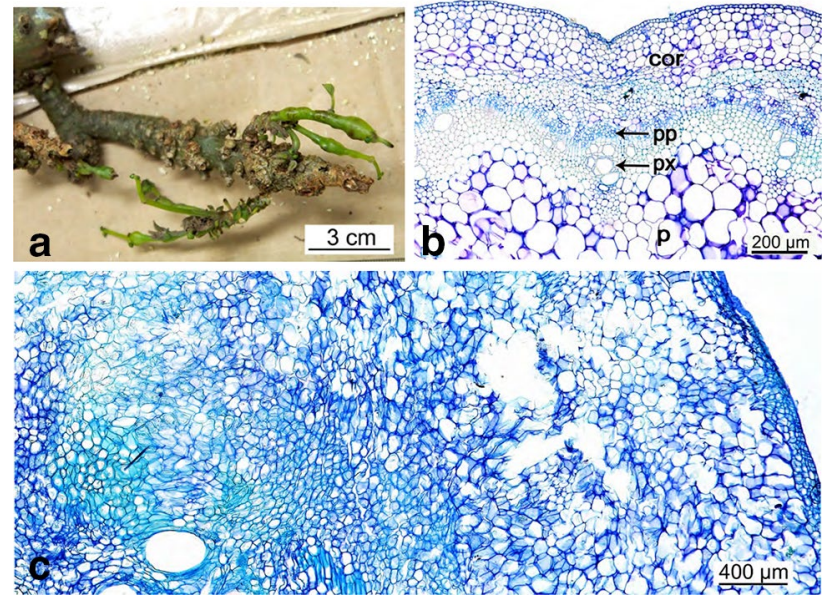

Fig. 5 Petiole structure of E. variegata with or without galls of Quadrastichus erythrinae. a Shoot with galls of $Q$. erythrinae. b Cross section of normal petiole tissue showing clear boundaries of cortex (cor), primary phloem (pp), primary xylem (px), and pith (p). c Abnormal tissue in petiole with a gall showing hyperplasia and hypertrophy of cells. Sections $\mathbf{b}$ and $\mathbf{c}$ were stained with toluidine blue $\mathrm{O}$

transpiration was very active, meaning that the water supply to shoots and leaves was insufficient even in tree P3, which had abundant leaves.
Effect of Fusarium spp. and F. solani after inoculation of seedlings

In the preliminary inoculation of healthy seedlings, isolates P1-160OA7 (strain A) and R1-BC6 (strain B), which were detected in trees P1 and R1 (Table 2), induced brownish discoloration in the xylem and necrosis in the phloem. We then inoculated the roots with strains A (P2-f11) and B (P2f22) each one singly or with a mixture (Table 3, footnote). The mixture of strains A and B killed a seedling in 26 days, and strain A killed another seedling in 35 days (Fig. 7). The lower stems became soft (Fig. 7b, c), and at the microscopic level, cell necrosis was similar to that seen from decline of tree in the field. Whitish hyphae emerged from the necrotic area of the lower stems (Fig. 7c) and were confirmed as inoculated strain A. Seedlings inoculated with strain B did not show symptoms. On the 46th day after inoculation, November 17 , one of the control seedlings died without phloem necrosis following defoliation, and strains A and B were not isolated from the dead tissue.

In the third experiment, among nine inoculated seedlings, three seedlings died during the third to sixth weeks after inoculation, and seven seedlings developed slight symptoms, such as leaf yellowing and partial defoliation, then recovered. All seedlings inoculated with strain A, dead or surviving, had xylem discoloration and necrosis of the cortex and phloem in the lower stems and an odor. Strain A
Fig. 6 Maximum likelihood (ML) phylogenetic tree based on $E F$-1a nucleotide sequences. Numbers at nodes represent bootstrap support $>50 \%$ from 1000 replicates. Three clades in the FSSC and the Ambrosia Fusarium Clade were indicated by bold internodes. Accession numbers and NRRL (the ARS Culture Collection) or FRC (Fusarium Research Center) numbers are shown

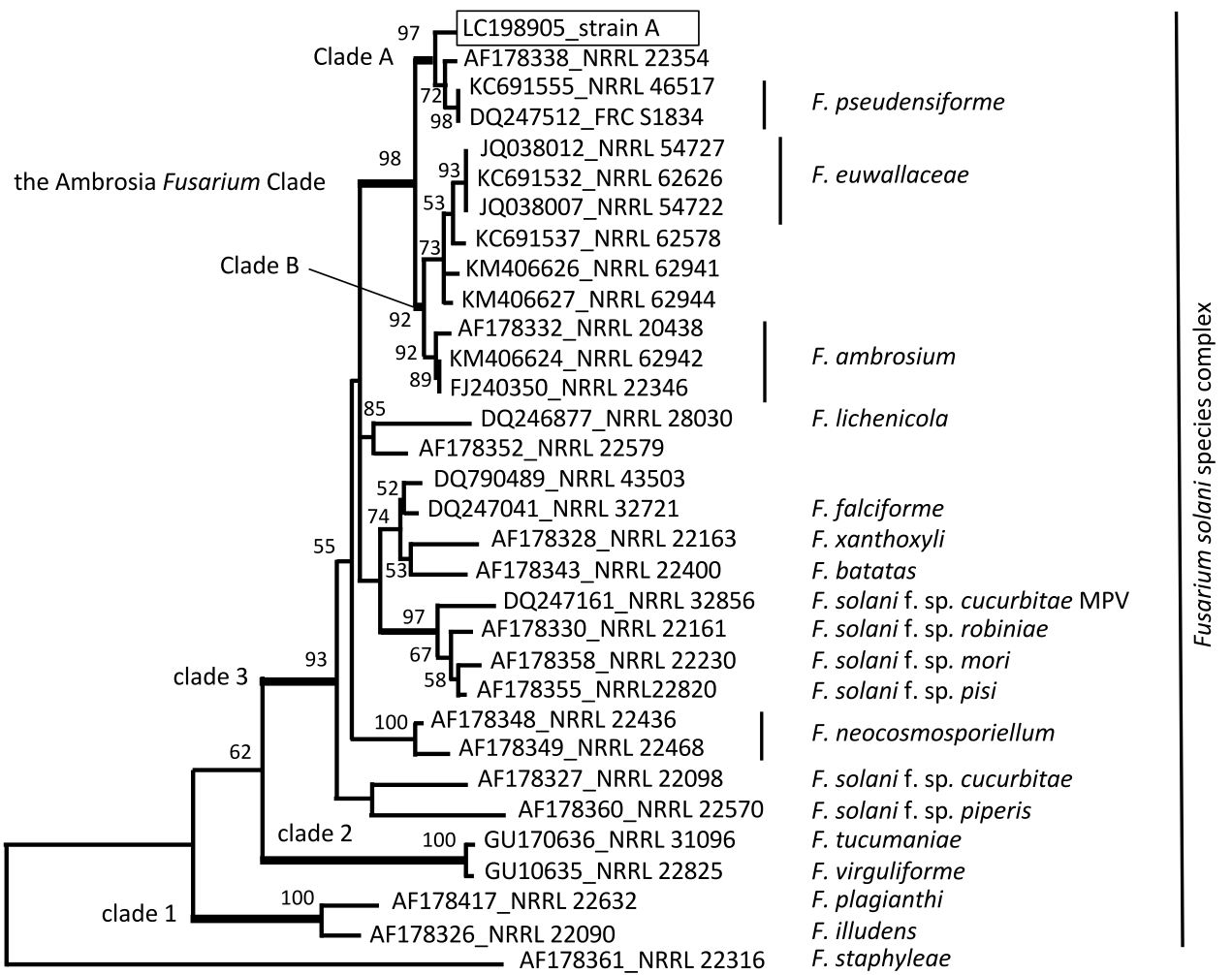




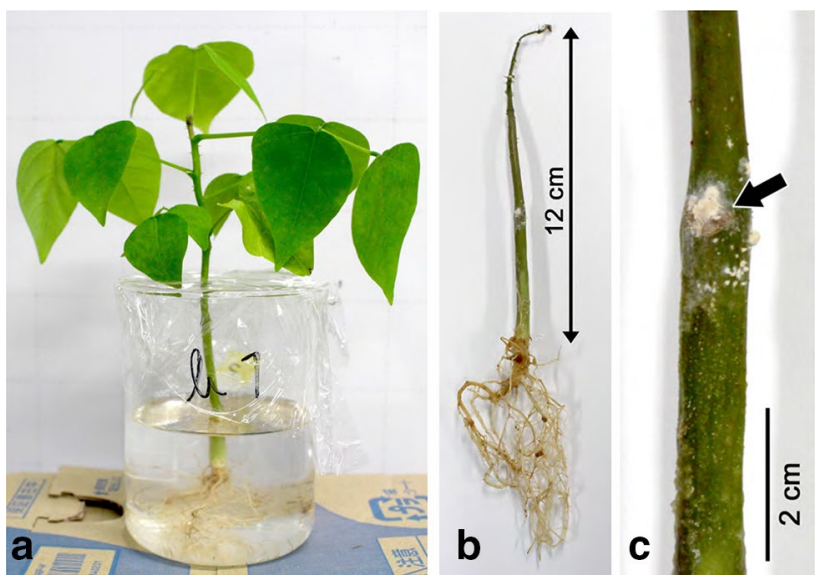

Fig. 7 E. variegata seedlings either non-inoculated or inoculated with a mixture of conidia of strains A and B. a Healthy seedling. b Dead seedling, 26 days after inoculation. c Whitish hyphae (arrow) from softened and necrotic tissue from the dead seedling in image $\mathbf{b}$

was reisolated from all inoculated specimens. In contrast, two control seedlings inoculated with sterilized toothpicks showed no symptoms, and strain A was not isolated.

\section{Discussion}

Brown to gray discoloration of the xylem in the lower trunk or thick branch was characteristic of the severely declining, defoliated $E$. variegata trees. This type of xylem discoloration is known as wound heartwood or pathological heartwood, caused by the defense reaction against infection; in turn, water conduction ceases in this area, as with normal heartwood (Hillis 1987). Brownish discoloration of the host tissue is caused by the secretion of secondary metabolites.

In the present study, loss of water conduction in declining trees was detected via the dye injection method, used in field and inoculation experiments to visualize water flow within specimens (Kuroda 2001; Morita et al. 2016). We found that water conduction had almost ceased in the heavily damaged E. variegata tree, which had wide discoloration in the basal part of the trunk, in Peace Memorial Park. In the slightly damaged tree, the water supply was insufficient, as evidenced by temporary leaf drooping during the daytime and the small amount of dye absorption. These results suggest that blockage of water conduction had progressed before the defoliation.

The causal relationship between xylem discoloration and water conduction blockage in trees has been well explained in reports on wilt diseases of trees. For instance, Japanese oak wilt caused by Raffaelea quercivora and fig wilt (fig canker) caused by Ceratocystis ficicola are wilt diseases that induce severe discoloration in the xylem and the dysfunction of water conduits at the same time (Kajii et al. 2013; Kuroda
2001; Morita et al. 2016; Sumida et al. 2016). Infected trees die from the cessation of water conduction when the host defense is ineffective and the discolored and dysfunctional area has almost covered the entire cross section of the trunks (Kuroda 2001). This phenomenon is universal in wilt diseases of broadleaved trees.

We always detected fungi that belong to the Fusarium solani species complex (FSSC) from heavily deteriorated or almost dead trees. Some strains, including strains A and $\mathrm{B}$, might be causing the decline and death of $E$. variegata because these strains were predominantly isolated from the discolored xylem of declining trees, and fungal hyphae were observed in the same area using microscopy. The tylosis formation also indicates vessel dysfunction in the discolored areas. In addition, secretion duct occlusions in the specimens are a sign of a defense reaction, in contrast to other reports on Erythrina trees in which occlusions were not found (Teixeira et al. 2000; Silva et al. 2013). In the slightly damaged trees with abundant leaves, the xylem discoloration was partial and pale in color. The area with this defense reaction and discoloration seem to have expanded by harvest. The lack of isolation of fungi belonging to the FSSC from nondiscolored xylem supports the idea that the defense reaction of the host progressed in association with growth of strains of Fusarium sp.

Phloem necrosis with an odor always occurred adjacent to the discolored xylem, and the same strains of Fusarium spp. were detected in both areas. Therefore, we focused on the identification of isolated strains and inoculation experiments. Other fungi, the Papularia sp., Pestalotia sp., and Alternaria sp., isolated with very low frequency, were judged to be a secondary infection to the necrotic host tissue and were not considered further as candidates.

In the phylogenetic analysis, strain A was a member of the Ambrosia Fusarium clade (AFC), especially closely related to $F$. pseudensiforme, which is a member of Clade A of the AFC (Fig. 6) and known as the causal agent of Fusarium dieback of avocado (Eskalen et al. 2012; Kasson et al. 2013). The AFC belongs to FSSC clade 3, which is composed of pathologically important species of both humans and plants (Aoki et al. 2014; O’Donnell et al. 2008; Zhang et al. 2006). Strain A was always isolated from the discolored xylem and necrotic phloem of E. variegata before tree death. Ambrosia beetles, such as the tea shot-hole borer (Euwallacea fornicatus), is known as a vector of Fusarium spp. in the AFC (Eskalen et al. 2012; Kasson et al. 2013). Detailed field research will be necessary to understand the relationships between strain A detected in E. variegata and the fungal symbionts of ambrosia beetles. $F$. virguliforme, a member of the FSSC clade 2, is known to cause sudden death syndrome in the soybean Glycine max (Roy et al. 1997), which belongs to the same family, Fabaceae, as Erythrina. Several reports indicate similarities between the symptoms of 
soybean SDS and those of Erythrina decline, such as the discoloration of stem tissue and tissue necrosis (Aoki et al. 2003, 2014; Roy et al. 1997). Note that the causal agent of SDS was confirmed only after a long history of investigation because experimental demonstration was difficult (Radwan et al. 2011).

Inoculation experiments in the present study were preliminary because seedling preparation was difficult and the experiments were done in a cooler climate than in the area where natural infection occurs. Nevertheless, seedlings inoculated with strain A died after the development of microscopic symptoms similar to those observed on naturally infected trees, and the inoculated strain was reisolated from all samples from symptomatic or dead seedlings. Therefore, we judged that at least one strain of the FSSC is pathogenic on E. variegata seedlings. Mortality rates typically are not as high in inoculation experiments for wilt diseases of trees (Morita et al. 2016), likely because xylem dysfunction progresses gradually in the host stems. So trees do not die until several years after infection. Repeated inoculation experiments should provide more information on disease development.

This incidence is a new discovery regarding the contribution of a fungus to the decline and death of $E$. variegata. Although the phylogenetic investigation of strains A and B within the FSSC is insufficient, reporting on this incidence is important for the development of new strategies to rescue Erythrina spp. If $Q$. erythrinae is not responsible for the decline of Erythrina trees, releasing Eurytoma erythrinae, a wasp indigenous to Africa, to biologically control Q. erythrinae in Hawaii (Bell et al. 2013; Yalemar et al. 2009) will be misdirected. This strategy will also need to be reconsidered in Japan's Okinawa Prefecture.

Strain A was mostly found in the lower part of severely damaged E. variegata trunks and in thick branches. Because Fusarium species mainly inhabit soil, spread of infection to adjacent trees may occur via root contact with infected roots or wounds in trunk bases, often caused by a lawn mower. Information from the prefectural government that the decline is progressing adjacent to dead trees also supports our prediction of fungal infection.

Based on the present observations, the contribution of $Q$. erythrinae to the xylem discoloration, phloem necrosis with odor, and death of Erythrina is doubtful. A defense reaction was not found around the galls of $Q$. erythrinae. Phloem necrosis was associated with xylem discoloration and was not observed around the galls. Detailed observation will be necessary to confirm the infection process and to determine whether $Q$. erythrinae is contributing to the decline of Erythrina. If it does not directly cause the tree's death, we need to assess whether the wasp is causing physiological stress to the hosts and promoting symptom development.
The slow defoliation of E. variegata trees over several years suggests that, although death appears to occur suddenly, xylem dysfunction may progress over many years. Infection by strain A indicated its pathogenicity to $E$. variegata seedlings; however, it may not be virulent enough to kill large trees in a short period. Perhaps a stressed condition is necessary to promote symptoms and cause death. Fungal strains should be collected from other sites in Japan and other areas where Erythrina decline is occurring to further examine the pathogenicity of this fungus. The distance of sampling sites, approximately $24 \mathrm{~km}$ between the University of the Ryukyus and Okinawa Prefectural Peace Memorial Park, suggests that the contribution of strain A to the E. variegata decline may be common over a wide area in Okinawa.

To conclude, Fusarium sp. may be a causal agent of xylem dysfunction and phloem necrosis in E. variegata. $Q$. erythrinae does not seem to contribute to the decline and death, since xylem discoloration and the distribution of pathogenic strain A were not found around the galls of $Q$. erythrinae. In addition, we obtained information that Fusarium $\mathrm{sp}$. had been detected in an E. crista-galli specimen that died suddenly three decades ago in Kagoshima (J. Miyajima, Kumamoto Prefectural Government, personal communication), where $Q$. erythrinae was not present. These observations suggest that the sudden death of Erythrina occurs without $Q$. erythrinae infestation. Still, $Q$. erythrinae could promote the decline of its hosts through physiological stress. Stressed E. variegata may become susceptible to strain A. If the decline and death of $E$. variegata increased after the $Q$. erythrinae spread throughout the southern islands of Japan, the role of this wasp must be investigated from a pathological perspective. Although we need detailed investigations to elucidate the entire process of Erythrinae decline and death, information on the pathogenicity of strain A to $E$. variegata will be helpful in developing methods to protect hosts. Injecting insecticide into trunks does not stop Erythrinae sudden death. So an alternative treatment, fungicide injection, may prevent xylem colonization by strain A and maintain the ascent of sap. We have begun test injections of a fungicide that is popular for protecting oak trees from Japanese oak wilt.

Acknowledgements The authors are grateful to Dr. Takayuki Aoki (National Institute of Agrobiological Sciences, Genetic Resources Center) for his advice on the phylogenetic analysis of Fusarium spp. We also thank the Okinawa Prefectural Forest Resource Research Center and Ryukyu Sankei Co., Ltd., for supplying E. variegata seedlings for inoculation experiments. This work was supported by JSPS KAKENHI Grant Number JP15K14747 and by Okinawa Prefecture.

Open Access This article is distributed under the terms of the Creative Commons Attribution 4.0 International License (http:// creativecommons.org/licenses/by/4.0/), which permits unrestricted use, distribution, and reproduction in any medium, provided you give 
appropriate credit to the original author(s) and the source, provide a link to the Creative Commons license, and indicate if changes were made.

\section{References}

Aoki T, O'Donnell K, Homma Y, Lattanzi AR (2003) Sudden-death syndrome of soybean is caused by two morphologically and phylogenetically distinct species within the Fusarium solani species complex-F. virguliforme in North America and F. tucumaniae in South America. Mycologia 95:660-684

Aoki T, O'Donnell K, Geiser DM (2014) Systematics of key phytopathogenic Fusarium species:current status and future challenges. J Gen Plant Pathol 80:189-201

Barnett HL, Hunter BB (1998) Illustrated genera of imperfect fungi, 4th edn. APS Press, St. Paul, p. 218

Bell RC, Belmaker A, Couch CS, Marchetto KM, Simonis JL, Thomas RQ, Spark JP, Brown JM, Francisco KS, Manuel ME (2013) Effectiveness of Erythrina gall wasp biocontrol and implications for the recovery of threatened Wiliwili trees (Fabaceae: Erythrina sandwicensis). J Torrey Bot Soc 140:215-224

Costa SS, Matos KS, Tessmann DJ, Seixas CDS, Pfenning LH (2016) Fusarium paranaense sp. nov., a member of the Fusarium solani species complex causes root rot on soybean in Brazil. Fungal Biol 120:51-60

Culik MP, Martins DDS, Ventura JA, Costa VA (2014) The invasive gall wasp Quadrastichus erythrinae (Hymenoptera: Eulophidae) in South America: is classical biological control needed? Biocontrol Sci Techn 24(8):971-975

Eskalen A, Gonzalez A, Wang DH, Twizeyimana M, Mayorquin JS, Lynch SC (2012) First report of a Fusarium sp. and its vector tea shot hole borer (Euwallacea fornicatus) causing Fusarium dieback on avocado in California. Plant Dis 96:1070

Faizal MH, Prathapan KD, Anith KN, Mary CA, Lekha M, Rini CR (2006) Erythrina gall wasp Quadrastichus erythrinae, yet another invasive pest new to India. Curr Sci 90:1061-1062

Feder N, O’Brien TP (1968) Plant microtechnique: some principles and new methods. Am J Bot 55:123-139

Gramling C (2005) Hawaii's coral trees feel the sting of foreign wasps. Science 310:1759-1760

Heu RA, Tsuda DM, Nagamine WT, Yalemar JA, Suh TH (2008) Erythrina gall wasp Quadrastichus erythrinae Kim (Hymenoptera: Eulophidae). New Pest Advisory No. 05-03, Hawaii Department of Agriculture, Honolulu

Hillis WE (1987) Heartwood and tree exudates. Springer-Verlag, Berlin, pp 157-162

Jukes TH, Cantor CR (1969) Evolution of protein molecules. In: Munro HN (ed) Mammalian protein metabolism. Academic Press, New York, pp 21-132

Kajii C, Morita T, Jikumaru S, Kajimura H, Yamaoka Y, Kuroda K (2013) Xylem dysfunction in Ficus carica infected with wilt fungus Ceratocystis ficicola and the role of the vector beetle Euwallacea interjectus. IAWA J 34:301-312

Kasson MT, O'Donnell K, Rooney AP, Sink S, Ploetz RC, Ploetz JN, Konkol JL, Carrillo D, Freeman S, Mendel Z, Smith JA, Black AW, Hulcr J, Bateman C, Stefkova K, Campbell PR, Geering AD, Dann EK, Eskalen A, Mohotti K, Short DP, Aoki T, Fenstermacher KA, Davis DD, Geiser DM (2013) An inordinate fondness for Fusarium: phylogenetic diversity of fusaria cultivated by ambrosia beetles in the genus Euwallacea on avocado and other plant hosts. Fungal Genet Biol 56:147-157

Kihara T, Murakami T, Chuma I, Kameyama N, Kuroda K (2016) A pathological and anatomical study on the factor of phloem necrosis and wilt of Erythrina variegata (in Japanese). Tree Forest Health 20:95-96

Kim IK, Delvare G, La Salle J (2004) A new species of Quadrastichus (Hymenoptera: Eulophidae): a gall-inducing pest on Erythrina (Fabaceae). J Hymenoptera Res 13(2):243-249

Kiyuna C (2008) Effect of a pesticide injection to Erythrina variegata to kill Quadrastichus erythrinae (in Japanese). Res Rep Okinawa Prefect For Resour Res Cent 50:10-1

Kumar S, Stecher G, Tamura K (2016) MEGA7: Molecular evolutionary genetics analysis version 7.0 for bigger datasets. Mol Biol Evol 33:1870-1874

Kuroda K (2001) Responses of Quercus sapwood to infection with the pathogenic fungus of a new wilt disease vectored by the ambrosia beetle Platypus quercivorus. J Wood Sci 47:425-429

Kuroda K (2005) Xylem dysfunction in Yezo spruce (Picea jezoensis) after inoculation with the blue-stain fungus Ceratocystis polonica. For Pathol 35:346-358

Kuroda K, Yamada T (1996) Discoloration of sapwood and blockage of xylem sap ascent in the trunks of wilting Quercus spp. following attack by Platypus quercivorus (in Japanese with English summary). J Jpn For Soc 78:84-88

Morita T, Jikumaru S, Kuroda K (2016) Disease development in Ficus carica plants after inoculation with Ceratocystis ficicola. (1) relationships between xylem dysfunction and wilt symptom (in Japanese with English summary). Jpn J Phytopathol 82:301-309

O'Donnel K, Sarver BA, Brandt M, Chang DC, Noble-Wang J, Park BJ, Sutton DA, Benjamin L, Lindsley M, Padhye A, Geiser DM, Ward TJ (2007) Phylogenetic diversity and microsphere array-based genotyping of human pathogenic Fusaria, including isolates from the multistate contact lens-associated U.S. keratitis outbreaks of 2005 and 2006. J Clin Microbiol 45:2235-2248

O'Donnell K (2000) Molecular phylogeny of the Nectria haematococca-Fusarium solani species complex. Mycologia 92:919-938

O’Donnell K, Sutton DA, Fothergill A, McCarthy D, Rinaldi MG, Brandt ME, Zhang N, Geiser DM (2008) Molecular phylogenetic diversity, multilocus haplotype nomenclature, and in vitro antifungal resistance within the Fusarium solani species complex. J Clin Microbiol 46:2477-2490

O’Donnell K, Sink S, Libeskind-Hadas R, Hulcr J, Kasson MT, Ploetz RC, Konko JL, Ploetz JN, Carrillo D, Campbell A, Duncan RE, Liyanage PNH, Eskalen A, Na F, Geiser DM, Bateman C, Freeman S, Mendel Z, Sharon M, Aoki T, Cossé AA, Rooney AP (2015) Discordant phylogenies suggest repeated host shifts in the Fusarium-Euwallacea ambrosia beetle mutualism. Fungal Genet Biol 82:277-290

Radwan O, Liu Y, Clough SJ (2011) Transcriptional analysis of soybean root response to Fusarium virguliforme, the causal agent of sudden death syndrome. Mol Plant-Microbe Interact 24:958-972

Reimar NJ (2007) Field release of Eurytoma sp. (Hymenoptera: Eurytomidae), for biological control of the Erythrina gall wasp, Quadrastichus erythrinae Kim (Hymenoptera: Eulohidae), in Hawaii. Draft Environmental Assessment, p 8

Roy KW, Rupe JC, Hershman DE, Abney TS (1997) Sudden death syndrome of soybean. Plant Dis 81:1100-1111

Rubinoff D, Holland BS, Shibata A, Messing RH, Wright MG (2010) Rapid invasion despite lack of genetic variation in the Erythrina gall wasp (Quadrastichus erythrinae Kim). Pacific Sci 64:23-31

Ruzin SE (1999) Plant microtechnique and microscopy. Oxford University, New York, pp 87-95

Silva MB da, Santana ASCO, Pimentel RMM, Silva FCL, Randau KP, Soares LAL (2013) Anatomy of leaf and stem of Erythrina velutina. Rev Bras Farmacogn 23:200-206

Sumida S, Kajii C, Morita T, Kuroda K (2016) Disease development in Ficus carica seedlings after inoculation with Ceratocystis ficicola. (2) microscopicanalysisofthehost-pathogeninteractionandinternal- 
symptoms (Japanese with English summary). Jpn J Phytopathol $82: 310-316$

Teixeira SDP, Castro MDM, Tozzi ADA (2000) Secretory cavities and pellucid dots in leaflets of Lonchocarpus (Leguminosae, Papilionoideae, Millettieae). Plant System Evol 221:61-68

Uechi N, Uesato T, Yukawa J (2007) Detection of an invasive gallinducing pest, Quadrastichus erythrinae (Hymenoptera: Eulophidae), causing damage to Erythrina variegata L. (Fabaceae) in Okinawa Prefecture, Japan. Entomol Sci 10:209-212

White TJ, Bruns T, Lee S, Taylor J (1990) Amplification and direct sequencing of fungal ribosomal RNA genes for phylogenetics. In: Innis MA, Gelfand DH, Sninsky JJ, White TJ (eds.) PCR protocols: a guide to methods and applications. Academic Press, San Diego, pp 315-322
Yalemar J, Nagamine W, Ramadan M, Bautista R (2009) Managing the Erythrina gall wasp problem in Hawaii by classical biological control. Presentation of State of Hawaii Department of Agriculture, Honolulu, p. 27

Yang MM, Tung GS, LaSalle J, Wu ML (2004) Outbreak of erythrina gall wasp (Hymenoptera: Eulophidae) on Erythrina spp. (Fabaceae). Taiwan. Plant Protect Bull 46:391-396

Zhang N, O'Donnell K, Sutton DA, Nalim FA, Summerbell RC, Padhye AA, Geiser DM (2006) Members of the Fusarium solani species complex that cause infections in both humans and plants are common in the environment. J Clin Microbiol 44:2186-2190 